\title{
The Use of Recombinant Pseudotype Virus-Like Particles Harbouring Inserted Target Antigen to Generate Antibodies against Cellular Marker p16 ${ }^{\mathrm{INK} 4 \mathrm{~A}}$
}

\author{
Rita Lasickienè, ${ }^{1}$ Alma Gedvilaite, ${ }^{1}$ Milda Norkiene, ${ }^{1}$ Vaida Simanaviciene, ${ }^{1}$ Indre Sezaite, ${ }^{1}$ \\ Dovile Dekaminaviciute, ${ }^{1}$ Evelina Shikova, ${ }^{2}$ and Aurelija Zvirbliene ${ }^{1}$ \\ ${ }^{1}$ Institute of Biotechnology, Vilnius University, Graiciuno 8, 02241 Vilnius, Lithuania \\ ${ }^{2}$ Institute of Experimental Morphology, Pathology and Anthropology with Muzeum, Bulgarian Academy of Sciences, \\ Acad. G. Bonchev Street, Building 25, 1113 Sofia, Bulgaria
}

Correspondence should be addressed to Aurelija Zvirbliene, azvirb@ibt.lt

Received 29 October 2011; Accepted 20 November 2011

Academic Editor: Angelo A. Manfredi

Copyright (C) 2012 Rita Lasickiene et al. This is an open access article distributed under the Creative Commons Attribution License, which permits unrestricted use, distribution, and reproduction in any medium, provided the original work is properly cited.

\begin{abstract}
Protein engineering provides an opportunity to generate new immunogens with desired features. Previously, we have demonstrated that hamster polyomavirus major capsid protein VP1-derived virus-like particles (VLPs) are highly immunogenic and can be employed for the insertion of foreign epitopes at certain surface-exposed positions. In the current study, we have designed pseudotype VLPs consisting of an intact VP1 protein and VP2 protein fused with the target antigen—cellular marker p16 $6^{\mathrm{INK} 4 \mathrm{~A}}$-at its $\mathrm{N}$ terminus. Both proteins coexpressed in yeast were self-assembled to pseudotype VLPs harbouring the inserted antigen on the surface. The pseudotype VLPs were used for generation of antibodies against $\mathrm{p} 16^{\mathrm{INK} 4 \mathrm{~A}}$ that represents a potential biomarker for cells transformed by high-risk human papillomavirus (HPV). The pseudotype VLPs induced in immunized mice a strong immune response against the target antigen. The antisera raised against pseudotype VLPs showed specific immunostaining of p16 $6^{\mathrm{INK} 4 \mathrm{~A}}$ protein in malignant cervical tissue. Spleen cells of the immunized mice were used to generate monoclonal antibodies against $\mathrm{p} 16^{\mathrm{INK} 4 \mathrm{~A}}$ protein. The specificity of antibodies was proven by the immunostaining of HPV-transformed cells. In conclusion, the current study demonstrates the potential of pseudotype VLPs with inserted target antigen as a new type of immunogens to generate antibodies of high diagnostic value.
\end{abstract}

\section{Introduction}

Gene and protein engineering provides an opportunity to generate novel chimeric proteins with desired features, such as enhanced immunogenicity. Structural proteins originating from human and animal viruses, for example, papilloma, hepatitis B, and parvo- and rotaviruses with their intrinsic capacity to self-assemble to highly organized structuresvirus-like particles (VLPs) - have been shown to possess high immunogenicity and therefore exploited as potential vaccines [1-3]. Moreover, recombinant VLPs can be employed as carriers for non immunogenic proteins or peptides in order to enhance their immunogenicity. Previous studies demonstrated that insertions/fusions of foreign protein segments at certain sites of VLP carriers derived from papilloma-, polyoma-, hepadna-, parvo-, and retroviruses did not influence protein folding and assembly of chimeric VLPs. The immunogenicity of foreign sequences presented on the surface of chimeric VLPs is enhanced making these VLPs promising vaccine candidates [4-7]. Recently, we have demonstrated that hamster polyomavirus $(\mathrm{HaPyV})$ major capsid protein VP1-derived VLPs are highly immunogenic and tolerate inserts of different size and origin at certain surface-exposed positions. The chimeric HaPyV-VP1 VLPs have been shown to activate efficiently the antigenpresenting cells and induce strong insert-specific B- and Tcell responses in mice $[8,9]$. These studies demonstrated that chimeric VLPs represent promising novel immunogens to generate monoclonal antibodies (MAbs) of the desired epitope-specificity. The main advantage of chimeric VLPs 
over tradicional immunogens such as synthetic peptides chemically coupled to carrier proteins is the exposure of the target sequence on the surface of VLPs thus allowing its accessibility to the B cells [9]. Although chimeric VLPs tolerate inserts up to 120 amino acid (aa) residues, the insertion of longer protein sequences generally affects proper folding and self-assembly of VLPs (our unpublished observation). Therefore, new approaches for enhancing the immunogenicity of long protein segments or full-length proteins are needed. This is especially important for human cellular proteins that may be tolerogenic in mice because of high homology with murine proteins. Strong immunogens presenting the target protein sequence on a suitable carrier may break the tolerance barrier and increase the immunogenicity of non-immunogenic proteins or protein segments.

In the current study, we designed novel recombinant immunogens based on pseudotype VLPs consisting of two $\mathrm{HaPyV}$-derived capsid proteins-an intact VP1 protein and modified VP2 protein harbouring the target protein sequence at VP2 N terminus. As a target sequence, we have used full-length cellular protein of high diagnostic relevance p $16^{\text {INK4A }}$ that is considered to be a potential marker for cells transformed by high-risk human papillomavirus (HPV). We have demonstrated that pseudotype VLPs consisting of an intact VP1 protein and VP2 protein fused with the $\mathrm{p} 16^{\mathrm{INK} 4 \mathrm{~A}}$ antigen at its $\mathrm{N}$ terminus induced a strong antibody response against the target sequence which allowed generation of p16 ${ }^{\mathrm{INK} 4 \mathrm{~A}}$-specific MAbs.

\section{Materials and Methods}

2.1. Production of Pseudotype VLPs Harbouring Full-Length p16 $6^{\text {INK4A }}$ Protein. All DNA manipulations were carried out according to standard procedures [10]. Enzymes and kits for DNA manipulations were purchased from Thermo Scientific Fermentas (Vilnius, Lithuania). Recombinant plasmids were screened in E.coli DH10B cells. The synthetic gene encoding the full length $\mathrm{p} 16^{\mathrm{INK} 4 \mathrm{~A}}$ protein (synthesized by Integrated DNA Technologies, BVBA, Leuven, Belgium) was fused to hamster polyomavirus ( $\mathrm{HaPyV}$ ) VP2 gene modified at its $\mathrm{N}$ terminus in the plasmid pFGG3-VP1/VP2Bg. This plasmid was constructed by inserting HaPyV VP1 gene into GAL 7 expression cassette and modified $\mathrm{HaPyV}$ VP2 gene under GAL10-PYK1 hybrid promoter into yeast expression vector pFGG3 [11]. To construct the modified HaPyV VP2 gene, the sequence encoding 1-100 aa was deleted and GSS linker coding sequence and the BglII restriction site were introduced at its $\mathrm{N}$ terminus for a fusion with $\mathrm{p} 16^{\mathrm{INK} 4 \mathrm{~A}}$ coding sequence. The resulting plasmid pFGG3-VP1/VP2-p16 was used for the transformation of the Saccharomyces cerevisiae strain AH22214 (a, leu2-3, 112, his4-519). Transformed yeast cells were grown in YEPD medium (yeast extract $1 \%$, peptone $2 \%$, and glucose $2 \%$ ) supplemented with $5 \mathrm{mM}$ formaldehyde at $30^{\circ} \mathrm{C}$. The production of the recombinant protein was induced after $24 \mathrm{~h}$ of cultivation by adding galactose until $3 \%$ final concentration. After $18 \mathrm{~h}$ growth the yeast cells were harvested by centrifugation and stored at $-20^{\circ} \mathrm{C}$ until use. The expression of recombinant VP1 and VP2 proteins was verified by gel electrophoresis and Western blot analysis of the yeast cell lysate as decribed hereinafter.

\subsection{Purification and Electron Microscopy Analysis of Pseudo-} type VLPs. S. cerevisiae yeast biomass harbouring recombinant proteins was resuspended and homogenized in DB 450 buffer $\left(450 \mathrm{mM} \mathrm{NaCl}, 1 \mathrm{mM} \mathrm{CaCl}_{2}, 0.001 \%\right.$ Trition X-100, $0.25 \mathrm{M}$ L-Arginine in $10 \mathrm{mM}$ Tris/HCl-buffer, $\mathrm{pH}$ 7.2) containing $2 \mathrm{mM}$ phenylmethylsulfonyl fluoride (PMSF) and EDTA-free Complete Protease Inhibitor Cocktail (Thermo Scientific Fermentas) and mechanically disrupted using French press. After centrifugation, the supernatant was collected and loaded onto a $20-60 \%$ sucrose gradient. After centrifugation at 25,000 rpm (Rotor SW28, Beckman, USA) overnight the fractions of $0.5 \mathrm{~mL}$ were collected and subjected to SDS-PAGE. The fractions containing proteins of 42 and $45 \mathrm{kDa}$ corresponding to VP1 and $\mathrm{p} 16^{\mathrm{INK} 4 \mathrm{~A}}$ fused with VP2 (VP2-p16 ${ }^{\mathrm{INK} 4 \mathrm{~A}}$ ), respectively, were pooled and diluted in buffer DB $150\left(150 \mathrm{mM} \mathrm{NaCl}, 1 \mathrm{mM} \mathrm{CaCl}_{2}\right.$ and $0.001 \%$ Trition $\mathrm{X}-100$ in $10 \mathrm{mM}$ Tris/HCl-buffer $\mathrm{pH}$ 7.2). The mixture was subjected to ultracentrifugation overnight at $100,000 \times \mathrm{g}($ Beckman $)$ on $\mathrm{CsCl}$ gradient with densities from 1.23 to $1.42 \mathrm{~g} / \mathrm{mL}$. The collected fractions were analyzed as described previously. As recombinant VP1 and VP2p $16^{\mathrm{INK} 4 \mathrm{~A}}$ proteins were almost identical according to their molecular mass, the presence of VP2-p16 ${ }^{\mathrm{INK} 4 \mathrm{~A}}$ protein was verified by Western blot using in-house produced murine polyclonal antibodies against VP2 protein. Fractions containing VP1/VP2-p16 ${ }^{\mathrm{INK} 4 \mathrm{~A}}$ protein were diluted and precipitated by ultracentrifugation for $4 \mathrm{~h}$, then dissolved in phosphate buffered saline (PBS), and dialyzed against PBS. The dialyzed VP1/VP2-p16 ${ }^{\text {INK4A }}$ protein was aliquoted and lyophilized.

The VLP formation was verified by examination of the purified proteins by Morgagni 268 electron microscope (FEI Inc., Hillsboro, OR, USA). Protein samples were placed on 400-mesh carbon-coated palladium grids and negatively stained with $2 \%$ aqueous uranyl acetate.

2.3. Production of GST-Fused $p 16^{\mathrm{INK} 4 \mathrm{~A}}$ Protein. To produce p $16^{\mathrm{INK} 4 \mathrm{~A}}$ protein fused to glutathione S-transferase (GST) in E.coli, the DNA sequence encoding p16 $6^{\mathrm{INK} 4 \mathrm{~A}}$ protein was cloned into the expression vector pGEX-5x (Amersham). The resulted plasmid pGEX-5x-p16 was used to transform E.coli strain BL1. The expression of GST-fused p16 ${ }^{\mathrm{INK} 4 \mathrm{~A}}$ protein was confirmed by SDS-PAGE and Western blot analysis with anti-GST antibodies (GE Healthcare, Uppsala, Sweden). The GST-p16 $6^{\mathrm{INK} 4 \mathrm{~A}}$-fused protein was purified using Glutathione Sepharose 4 Fast Flow (GE Healthcare Bio-Sciences AB SE-751 84) following the manufacturer's recommendations.

\subsection{Immunization of Mice and Generation of Monoclonal} Antibodies. BALB/c mice (obtained from a breeding colony at the Department of Immunology of the Center for Innovative Medicine, Vilnius, Lithuania) were immunized at days 0,28 , and 56 by a subcutaneous injection of $50 \mu \mathrm{g}$ of either recombinant pseudotype VLPs harbouring $\mathrm{p} 16^{\mathrm{INK} 4 \mathrm{~A}}$ protein or purified GST-p16 ${ }^{\text {INK4A }}$-fused protein. For an 
initial immunization, the antigen was emulsified in complete Freund adjuvant (Sigma). Subsequent immunizations were performed without an adjuvant, with the antigen dissolved in PBS. Antisera were collected two weeks after the second injection and tested for the presence of antibodies specific to $\mathrm{p} 16^{\mathrm{INK} 4 \mathrm{~A}}$ protein. The mouse with the highest antibody titer against pseudotype VLPs was selected for the development of MAbs. Hybridomas were generated essentially as described by Kohler and Milstein [12]. Three days after the final injection, mouse spleen cells were fused with Sp2/0-Ag 14 mouse myeloma cells using polyethylene glycol 1500 (PEG/DMSO solution, HybriMax, Sigma). Hybrid cells were selected in growth medium supplemented with hypoxantine, aminopterin, and thymidine (50x HAT media supplement, Sigma-Aldrich, St. Louis, USA). Samples of supernatant from wells with viable clones were screened by an indirect enzyme-linked immunosorbent assay (ELISA) using recombinant VLPs and GST-fused $\mathrm{p} 16^{\mathrm{INK} 4 \mathrm{~A}}$ protein as described hereinafter. Hybridomas secreting specific antibodies to $\mathrm{p} 16^{\mathrm{INK} 4 \mathrm{~A}}$ protein were subcloned twice by a limiting dilution assay. Hybridoma cells were maintained in complete Dulbecco's modified Eagle's medium (DMEM, Biochrom) containing $15 \%$ fetal calf serum (Biochrom) and antibiotics. Antibodies in hybridoma culture supernatants were isotyped using the Mouse Monoclonal Antibody Isotyping kit (ISO2, Sigma) in accordance with the manufacturer's protocol. All procedures involving experimental mice were performed under controlled laboratory conditions in strict accordance with the Lithuanian and European legislation.

2.5. SDS-PAGE. Proteins were analysed by electrophoresis on $12.5 \%$ sodium dodecylsulfate-polyacrylamide gels (SDSPAGE) followed by Coomassie brilliant blue staining. The SDS-PAGE sample buffer (Thermo Scientific Fermentas) was added to the prepared protein samples, boiled for $5 \mathrm{~min}$, applied to a polyacrylamide gel, and run in SDS-Trisglycine buffer. Protein bands were visualized by staining with Coomassie brilliant blue (Sigma).

2.6. Western Blot Analysis. The proteins were separated by SDS-PAGE and electrotransferred to Immobilon P membrane (Millipore). The membranes were blocked with 5\% milk in PBS for $2 \mathrm{~h}$ at room temperature (RT). The membranes were then incubated for $1 \mathrm{~h}$ at RT with primary antibodies at working dilution and subsequently incubated with goat antimouse IgG conjugated to horseradish peroxidase (HRP) (Bio-Rad) diluted 1:2000 in PBS with $0.1 \%$ Tween 20 (PBST). The enzymatic reaction was developed using tetramethylbenzidine (TMB) ready-to-use chromogenic substrate (Sigma). As primary antibodies for the identification of VP1/VP2-p16 ${ }^{\mathrm{INK} 4 \mathrm{~A}}$ proteins, mouse MAb against $\mathrm{HaPyV}$ VP1, clone 3D10 [9], and polyclonal antibodies produced in-house against HaPyV VP2 protein were used (dilution $1: 1000$ in PBST). For analysing MAb specificity, undiluted hybridoma supernatants were used.

2.7. Indirect ELISA. Polystyrene microtiter plates (Nerbe) were coated with $100 \mu \mathrm{l} /$ well of the antigen diluted in coating buffer ( $0.05 \mathrm{M}$ sodium carbonate, $\mathrm{pH}$ 9.6) to a concentration of $5 \mu \mathrm{g} / \mathrm{mL}$ by incubation overnight at $4^{\circ} \mathrm{C}$. The coated plates were blocked with $150 \mu \mathrm{L} /$ well of $1 \%$ BSA for $2 \mathrm{~h}$ at RT. Plates were rinsed twice with PBST. Antiserum samples or hybridoma growth medium were diluted in PBST, added to the wells, and incubated for $1 \mathrm{~h}$ at RT. The plates were rinsed 3 times with PBST and incubated for $1 \mathrm{~h}$ with HRPconjugated goat antimouse IgG (Bio-Rad) diluted $1: 2000$ in PBST. The plates were rinsed 5 times with PBST. The enzymatic reaction was visualized by the addition of $100 \mu \mathrm{L}$ of ready-to-use TMB substrate (Sigma) to each well. After $10 \mathrm{~min}$ of incubation at RT, the reaction was stopped by adding $50 \mu \mathrm{L} /$ well of $10 \%$ sulphuric acid. The optical density (OD) was measured at $450 \mathrm{~nm}$ (reference filter $620 \mathrm{~nm}$ ) in a microplate reader (Tecan, Groedig, Austria).

2.8. Immunohistochemistry Analysis. Immunohistochemical staining was performed on paraffin-embedded samples of cervical squamous cell carcinomas and nonneoplastic cervical tissue selected from archival materials at the National Specialized Hospital for Active Treatment in Oncology, Sofia, Bulgaria. Haematoxylin and eosin-stained slides of all samples were reviewed by a pathologist and their histopathological diagnoses were reconfirmed. Sections (approximately $5 \mu \mathrm{m}$ thick) were cut and mounted on poly-l-lysine coated microscope slides (Thermo Scientific). Samples were deparaffinized in xylene and rehydrated in graded alcohols. Antigen retrieval was performed in $0.01 \mathrm{M}$ citrate buffer (pH 6.0) in a heating bath for $20 \mathrm{~min}$ at $97^{\circ} \mathrm{C}$. Endogenous peroxidase activity was blocked by incubating the sections in $3 \% \mathrm{H}_{2} \mathrm{O}_{2}$ for $5 \mathrm{~min}$. After blocking the nonspecific binding with 3\% BSA in PBS for $3 \mathrm{~h}$ at RT, slides were incubated with the primary antibody (mouse polyclonal antibody raised against pseudotype VLPs harbouring $\mathrm{p} 16^{\mathrm{INK} 4 \mathrm{~A}}$ protein; $1: 300$, or mouse polyclonal antibody raised against GSTp16 $6^{\mathrm{INK} 4 \mathrm{~A}}$ fused protein; $1: 100$ ) and left overnight in moist chambers at $4^{\circ} \mathrm{C}$. The bound antibody was visualized using a biotinylated secondary antibody, peroxidase-labelled streptavidin, and DAB substrate-chromogen (LSAB2 System-HRP, Dako, Denmark) according to the manufacturer's protocol. Sections were counterstained in hematoxylin, mounted and analyzed under light microscopy. As a negative control, irrelevant mouse polyclonal antibody raised against yeastexpressed hPIV3 nucleocapsid protein was used [13].

2.9. Flow-Cytometry. Adherent human cervical epithelial HeLa cells (ATCC Cat. No. CCL-2) were cultivated in RPMI-1640 growth medium (Biochrom, Berlin, Germany) supplemented with $10 \%$ fetal bovine serum (Biochrom) and antibiotics. The cells were grown at $37^{\circ} \mathrm{C}$ and $5 \% \mathrm{CO}_{2}$ to approximately $70 \%$ confluence, harvested, resuspended in Fixation/Permeabilization solution (BD Biosciences, Franklin Lakes, USA), and incubated for 20 minutes at $4^{\circ} \mathrm{C}$. The cells were washed two times with BD Perm/Wash buffer (BD Biosciences) and transferred to plastic tubes for immunofluorescent staining, $10^{6}$ cells per test. One hundred $\mu \mathrm{L}$ of BD Perm/Wash buffer containing $5 \mu \mathrm{g} / \mathrm{mL}$ of the MAb against $\mathrm{p} 16^{\mathrm{INK} 4 \mathrm{~A}}$ or appropriate positive and negative controls were added to the cells and incubated at $4^{\circ} \mathrm{C}$ for $30 \mathrm{~min}$. As a positive control, commercial 
anti-CDK2A/p16 ${ }^{\mathrm{INK} 4 \mathrm{~A}}$ MAb, clone DCS-50.1/H4 (Abcam, Cambridge, UK) was used $(10 \mu \mathrm{g} / \mathrm{mL})$. As a negative control, irrelevant MAb of IgG1 isotype against yeast-expressed hPIV3 nucleocapsid protein was used $(10 \mu \mathrm{g} / \mathrm{mL})$ [13]. After incubation, the cells were washed two times with $\mathrm{BD}$ Perm/Wash buffer and then incubated for $30 \mathrm{~min}$ at $4^{\circ} \mathrm{C}$ in the dark with $50 \mu \mathrm{L}$ of $\mathrm{BD}$ Perm/Wash buffer containing a predetermined optimal concentration of FITC-conjugated goat antimouse IgG (BD Pharmingen, Franklin Lakes, USA). Finally, the cells were washed two times with BD Perm/Wash buffer and resuspended in Staining Buffer (BD Pharmingen) prior to flow cytometric analysis. Cells were analyzed with CyFlow ${ }^{\mathrm{R}}$ space flow cytometer (Partec, Muenster, Germany). Not less than 20.000 events per test were evaluated with FloMax 2.7 software.

\section{Results}

Full-length human $\mathrm{p} 16^{\mathrm{INK} 4 \mathrm{~A}}$ protein $(16 \mathrm{kDa}, 133$ aa-long) was selected as a target protein for the generation of pseudotype VLPs and further immunization experiments. The alignment of aa sequences of human and murine p16 ${ }^{\mathrm{INK} 4 \mathrm{~A}}$ proteins using ClustalLW and BLAST computer programs revealed $75 \%$ sequence homology (Figure 1). High number of identical and similar aa residues indicated the low immunogenicity of human $\mathrm{p} 16^{\mathrm{INK} 4 \mathrm{~A}}$ in mice; therefore, the antigen was considered to be suitable as a target sequence for presenting on pseudotype VLPs.

For the construction of expression plasmids, synthetic gene encoding full-length $\mathrm{p} 16^{\mathrm{INK} 4 \mathrm{~A}}$ sequence was inserted into yeast expression vector $\mathrm{pFGG3-VP1/VP2Bg}$ designed for the coexpression HaPyV VP1 protein together with VP2 protein truncated until the 101 aa residue. The resulted plasmid pFGG3-VP1/VP2-p16 was used to transform yeast S.cerevisiae strain AH22-214. The SDS-PAGE analysis of crude lysates of transformed yeast cells revealed an overlapping protein band of approximately $42-45 \mathrm{kD}$ because the molecular mass of full-length VP1 protein and VP2p $16^{\text {INK4A }}$ fused protein was very similar ( 42 and $45 \mathrm{kD}$, resp.) (Figure 2(a), lane 2). The corresponding protein band was not visible in the lysate of yeast cells transformed with empty vector pFGG3 used as a negative control (Figure 2(a), lane 1). Protein bands representing the VP1 protein and VP2p16 $6^{\text {INK4A }}$ fused protein were specifically immunostained with the respective antibodies against HaPyV VP1 and VP2 proteins (Figures 2(b) and 2(c), lane 2). The soluble fraction of the lysate of transformed yeast cells was subjected to ultracentrifugation in sucrose and $\mathrm{CsCl}$ density gradients. The purified recombinant VP1/VP2-p16 ${ }^{\mathrm{INK} 4 \mathrm{~A}}$ proteins were analyzed by SDS PAGE and Western blot. According to SDSPAGE data, the purity of VP1/VP2-p16 $6^{\text {INK4A }}$ proteins after the ultracentrifugation step was about 99\% (Figure 2(a), lane 4). The identity of purified proteins was confirmed by Western blot analysis using specific antibodies (Figures 2(b) and 2(c), lane 4). Electron microscopy analysis of the purified negatively stained VP1/VP2-p16 ${ }^{\mathrm{INK} 4 \mathrm{~A}}$ proteins confirmed the formation of VLPs of about $45 \mathrm{~nm}$ in diameter (Figure 2(d)) similar in their size and shape to the nonmodified VP1/VP2 VLPs (Figure 2(e)) and to native viral capsids.

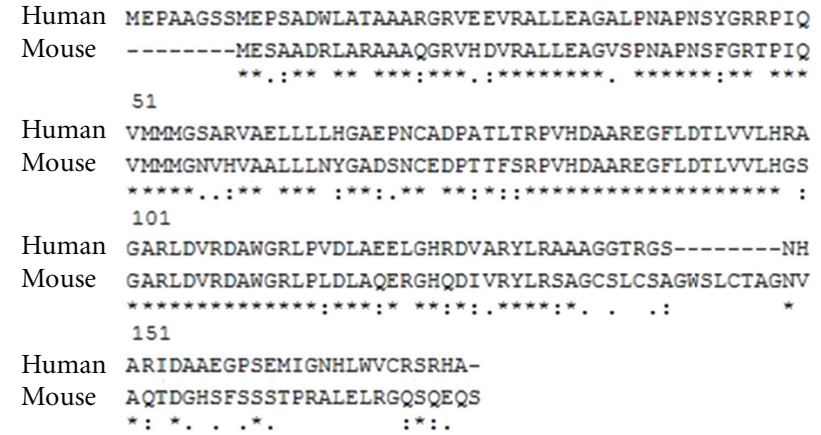

FIgURE 1: Alignment of aa sequences of human and murine p16 ${ }^{\mathrm{INK} 4 \mathrm{~A}}$ using ClustalLW computer program. Identical and similar aa residues are marked by asterisks and dots, respectively.

The pseudotype VLPs were used to immunize BALB/c mice to generate antibodies against the inserted target sequence. In parallel, the $\mathrm{BALB} / \mathrm{c}$ mice were immunized with purified GST-fused $\mathrm{p} 16^{\mathrm{INK} 4 \mathrm{~A}}$ protein. After 2 immunizations, the titers of antibodies specific to VP1/VP2-p16 $6^{\mathrm{INK} 4 \mathrm{~A}}$ determined by an indirect ELISA in the sera of mice immunized with pseudotype VLPs ranged from $1: 16000$ to $1: 32000$ (data not shown). To confirm the specificity of the antisera with $\mathrm{p} 16^{\mathrm{INK} 4 \mathrm{~A}}$ protein, their specificity was analyzed by Western blot using fused protein GST-p16 $6^{\mathrm{INK} 4 \mathrm{~A}}$ expressed in E.coli. Specific immunostaining of GST-p16 ${ }^{\mathrm{INK} 4 \mathrm{~A}}$ fuse was observed, which confirms that the antibodies raised against pseudotype VLPs recognize the $\mathrm{p} 16^{\mathrm{INK} 4 \mathrm{~A}}$ sequence (data not shown). In contrast, the antisera raised against GSTp $16^{\text {INK4A }}$ fused protein recognized only the antigen used for immunization (titers after 2 immunizations ranged $1: 4000$ $1: 12000)$ and did not show any reactivity with the $\mathrm{p} 16^{\text {INK4A }}$ sequence displayed on VLPs (data not shown).

To investigate the reactivity of the antisera with cellular p $16^{\mathrm{INK} 4 \mathrm{~A}}$ protein, they were applied to the immunohistochemistry analysis (IHC) of cervical tissue specimens. The antisera raised against pseudotype VLPs showed specific immunostaining of malignant cervical tissue containing HPV-transformed cells and did not react with nonneoplastic cervical tissue (Figure 3). This demonstrates the reactivity of the antisera raised against pseudotype VLPs with the cellular $\mathrm{p} 16^{\mathrm{INK} 4 \mathrm{~A}}$ protein present in malignant cervical tissue. In contrast, the antisera raised against GST-fused $\mathrm{p} 16^{\mathrm{INK} 4 \mathrm{~A}}$ protein did not show any reactivity in IHC (data not shown). Therefore, no further experiments with mice immunized with GST-p16 $6^{\mathrm{INK} 4 \mathrm{~A}}$ fused protein were performed.

Spleen cells of mice immunized with pseudotype VLPs were used to generate the MAbs against $\mathrm{p} 16^{\mathrm{INK} 4 \mathrm{~A}}$ protein. Three stable hybridoma cell lines producing p16 $6^{\mathrm{INK} 4 \mathrm{~A}}$ specific MAbs of IgG isotype (IgG1 subtype) were generated. The MAbs reacted specifically in Western blot both with pseudotype VP1/VP2-p16 ${ }^{\mathrm{INK} 4 \mathrm{~A}}$ VLPs and GST-p16 $6^{\mathrm{INK} 4 \mathrm{~A}}$ fuse but did not react either with yeast cell lysate or nonmodified VP1/VP2 VLPs used as a negative control (Figure 4). To prove the reactivity of the MAbs with native intracellular p $16^{\mathrm{INK} 4 \mathrm{~A}}$ protein, they were applied to flow-cytometry analysis of HeLa cells that represent HPV-18-transformed cervical 


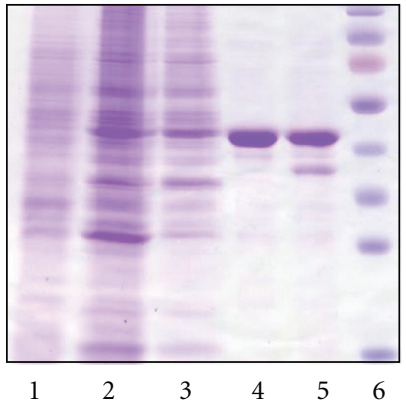

(a)

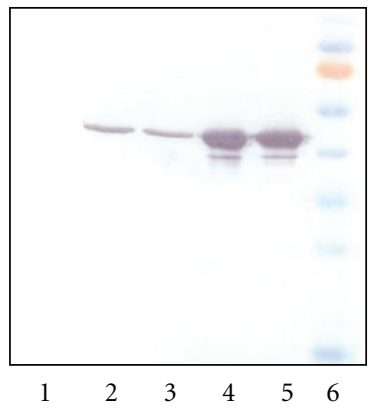

(b)

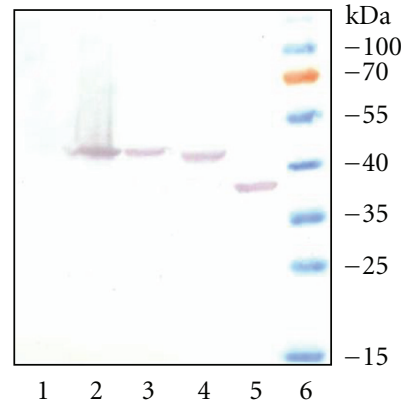

(c)

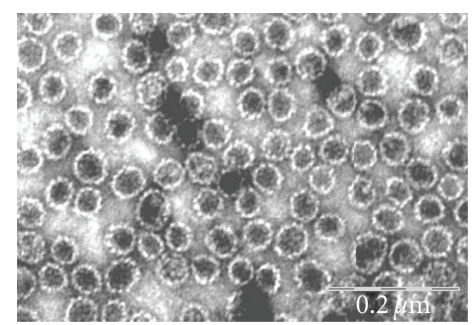

(d)

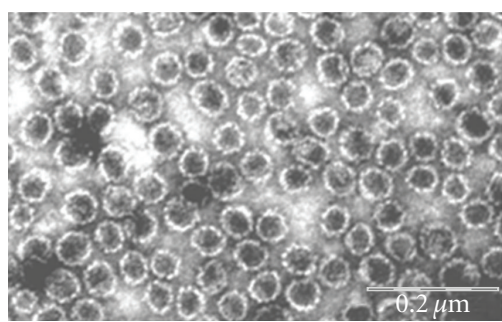

(e)

FIGURE 2: Analysis of the expression of VP1/VP2-p16 $6^{\mathrm{INK} 4 \mathrm{~A}}$ pseudotype VLPs in yeast. (a) Coomassie blue-stained SDS-PAGE. (b) Western blot with the MAb 3D10 against VP1 protein. (c) Western blot with polyclonal antibody against VP2 protein. The same samples were run on each gel. In lanes, there are (1) negative control sample from crude lysate of S. cerevisiae cells transformed with the empty vector pFGG3, (2) crude lysate of yeast transformed with pFGG3-VP1/VP2-p16 plasmid, (3) the soluble fraction recovered after centrifugation of crude lysate of yeast transformed with pFGG3-VP1/VP2-p16 plasmid, (4) VLPs consisting of VP1 protein and fusion protein VP2-p16 purified using sucrose and $\mathrm{CsCl}$ gradients, (5) VLPs consisting of VP1 protein and nonmodified VP2 protein purified using sucrose and CsCl gradients, and (6) prestained protein molecular mass marker (Thermo Scientific Fermentas). (d and e) Electron microscopy pictures of VP1/VP2p16 $6^{\text {INK4A }}(\mathrm{d})$ and nonmodified VP1/VP2 (e) pseudotype VLPs, stained with 2\% aqueous uranyl acetate solution and examined by Morgagni 268 electron microscope.

epithelial cells. The intracellular staining of HeLa cells confirmed the ability of the MAbs to recognize the intracellular native $\mathrm{p} 16^{\mathrm{INK} 4 \mathrm{~A}}$ and revealed about $65 \%$ of $\mathrm{p} 16^{\mathrm{INK} 4 \mathrm{~A}}$-positive cells (Figure 5(a)). The positivity of HeLa cells for p16 $6^{\mathrm{INK} 4 \mathrm{~A}}$ protein was confirmed by their specific immunostaining with the commercial MAb against $\mathrm{p} 16^{\mathrm{INK} 4 \mathrm{~A}}$ protein (Figure 5(b)). No specific immunostaining of HeLa cells was observed with an irrelevant MAb of the same isotype (Figure 5(c)). Thus, polyclonal and monoclonal antibodies raised against pseudotype VLPs harbouring the full-length $\mathrm{p} 16^{\mathrm{INK} 4 \mathrm{~A}}$ sequence were reactive with cellular native $\mathrm{p} 16^{\mathrm{INK} 4 \mathrm{~A}}$ protein. This is an indirect evidence that the $\mathrm{p} 16^{\mathrm{INK} 4 \mathrm{~A}}$ molecule displayed on the surface of pseudotype VLPs is natively folded.

In conclusion, our results demonstrate that pseudotype VLPs represent highly efficient carrier for cellular antigens and elicit a strong antibody response against the target protein presented on the surface of VLPs.

\section{Discussion}

The aim of the current study was to design novel recombinant antigen capable to display surface-exposed foreign protein sequences and enhance their immunogenicity. Such recombinant antigens may be applied for the generation of antibodies against cellular proteins of low immunogenicity. As a target protein for the construction of the recombinant antigen, we have selected the cellular marker $\mathrm{p} 16^{\mathrm{INK} 4 \mathrm{~A}}$ that represents an indirect indicator of cell cycle dysregulation associated with high-risk HPV infection. The expression of p16 $6^{\mathrm{INK} 4 \mathrm{~A}}$ is specifically induced in HPV-infected cells by HPV E7 protein that inactivates regulatory protein $\mathrm{pRb}$ (retinoblastoma gene product) and upregulates transcription factor E2F, which allows the $c d k$ gene transcription. The product of $c d k$ gene is protein $\mathrm{p} 16^{\mathrm{INK} 4 \mathrm{~A}}$. Several studies examined the $\mathrm{p} 16^{\mathrm{INK} 4 \mathrm{~A}}$ protein by immunocytochemical analysis and confirmed its diagnostic relevance as a biomarker for dysplastic squamous and glandular cells of the cervix [14-16].

Based on the alignment of aa sequences of human and murine $\mathrm{p} 16^{\mathrm{INK} 4 \mathrm{~A}}$ proteins that revealed high degree of homology, the low immunogenicity of human $\mathrm{p} 16^{\mathrm{INK} 4 \mathrm{~A}}$ in mice was predicted. To enhance its immunogenicity, we have constructed pseudotype VLPs consisting of an intact $\mathrm{HaPyV}$ VP1 protein and VP2 protein fused with the target antigenp16 ${ }^{\text {INK4A }}$ protein-at VP2 $\mathrm{N}$ terminus. Both recombinant proteins coexpressed in yeast S.cerevisiae were able to selfassemble to pseudotype VLPs harbouring the inserted target antigen. The shape and size of the pseudotype VLPs was similar to that observed for the native $\mathrm{HaPyV}$ capsids [17]. From the resolved crystal structures of the virions of SV-40 [18] and murine polyomavirus [19] it is known that the capsid of polyomaviruses mainly consists of 72 pentamers 


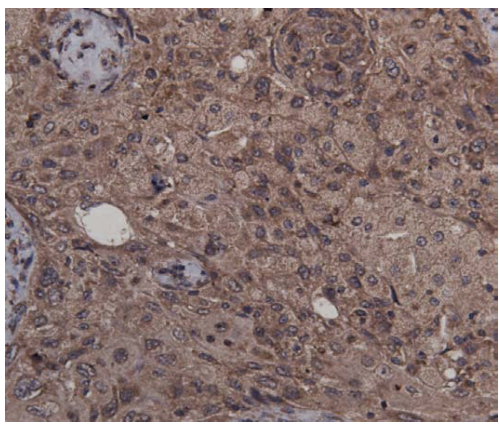

(a)

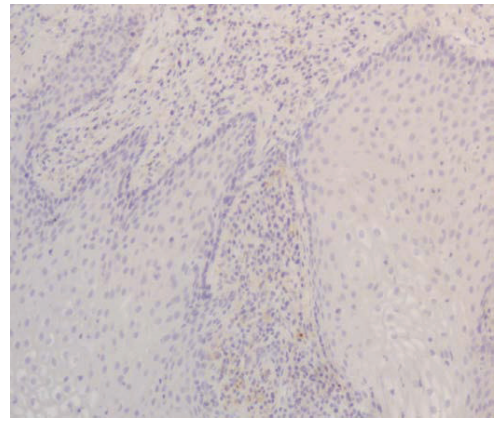

(b)

FIGURE 3: Immunohistochemical analysis of cervical tissues using mouse polyclonal antibody raised against pseudotype VLPs harbouring the p16 $6^{\mathrm{INK} 4 \mathrm{~A}}$ protein. (a) Invasive squamous cell carcinoma; (b) nonneoplastic cervical tissue (condyloma).

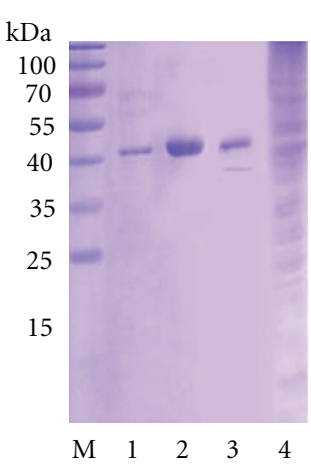

(a)

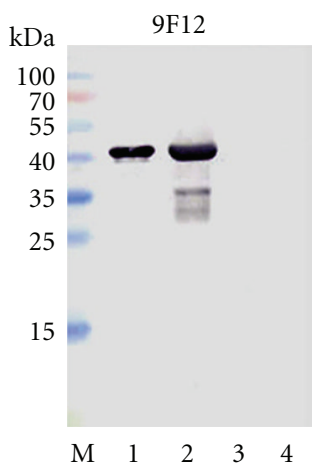

(b)

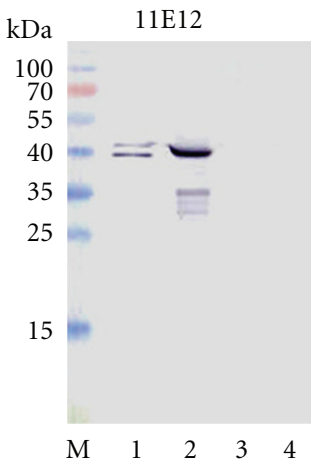

(c)

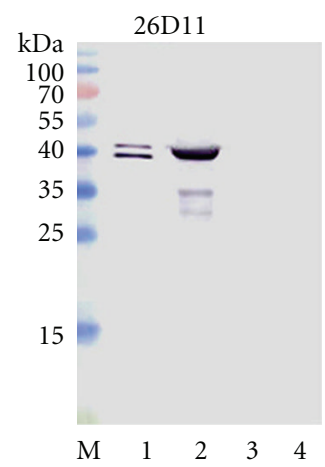

(d)

FIGURE 4: The reactivity of the MAbs raised against VP1/VP2-p16 $6^{\text {INK4A }}$ pseudotype VLPs with the p16 $6^{\text {INK4A }}$ protein sequence in Western blot. (a) Coomassie blue-stained SDS-PAGE. (b-d) Western blot with the MAbs raised against pseudotype VLPs, clones 9F12 (b), 11E12 (c), and $26 \mathrm{D} 11$ (d). Lane M: prestained protein molecular mass marker (Thermo Scientific Fermentas); lane 1: purified GST-fused p16 ${ }^{\mathrm{INK} 4 \mathrm{~A}}$ protein; lane 2: purified pseudotype VP1/VP2-p16 ${ }^{\text {INK4A }}$ VLPs; lane 3: purified nonmodified VP1/VP2 VLPs; lane 4: crude lysate of nontransformed $S$. cerevisiae cells.

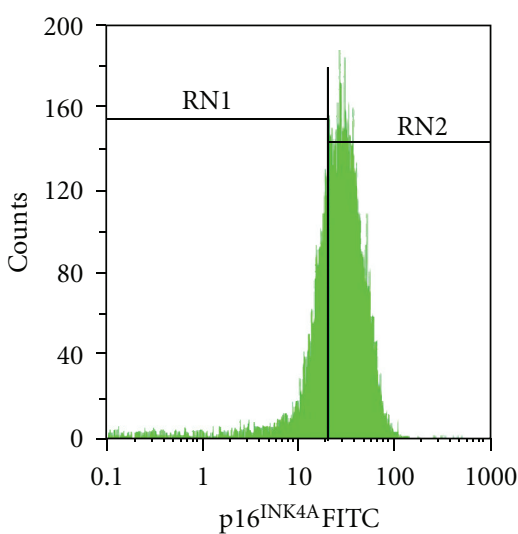

(a)

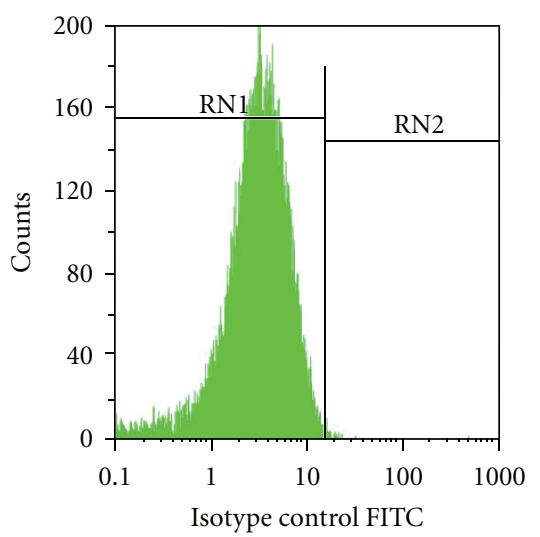

(b)

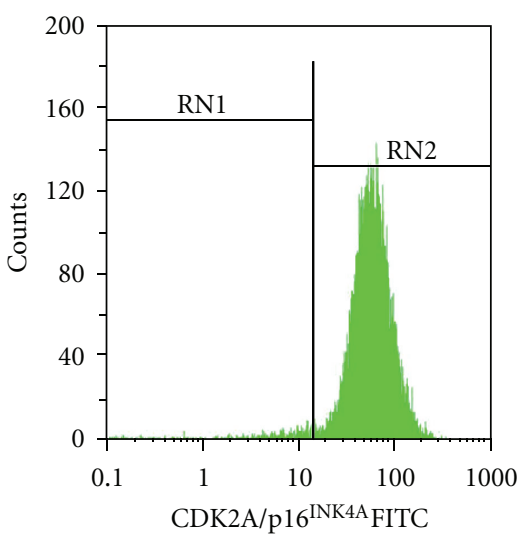

(c)

FIGURE 5: Flow-cytometry analysis of HeLa cells immunostained with the MAbs: (a) clone 9F12 (IgG1 subtype) raised against pseudotype VLPs harbouring the $16^{\mathrm{INK} 4 \mathrm{~A}}$ protein; (b) negative control, irrelevant Mab of IgG1 subtype; (c) positive control, commercial MAb against p16INK4A protein (Abcam). 
formed by 360 copies of the VP1 protein. One minor capsid protein, either VP2 or VP3, binds in the central 5-fold cavity of each VP1 pentamer [20]. The C terminal part of VP2 protein is necessary for it interaction with VP1 pentamer [20]; therefore, we have used the VP2 N-terminus to join the full-length p16 ${ }^{\mathrm{INK} 4 \mathrm{~A}}$ molecule. The ratio of VP1:VP2 proteins in HaPyV capsid is $360: 72$ [20]; consequently up to 72 chimeric VP2-p16 molecules might be incorporated into one VLP. It was supposed that the inserted $\mathrm{p} 16^{\mathrm{INK} 4 \mathrm{~A}}$ sequence will be displayed on the surface of pseudotype VLPs thus allowing its accessibility to the B cells. The immunogenicity of pseudotype VLPs in mice was proven by immunization experiments and subsequent generation of $\mathrm{p} 16^{\mathrm{INK} 4 \mathrm{~A}}$-specific MAbs. Polyclonal antibodies raised against pseudotype VLPs specifically recognized $\mathrm{p} 16^{\mathrm{INK} 4 \mathrm{~A}}$ sequence both by Western blot using recombinant E.coli-expressed GST-p16 ${ }^{\mathrm{INK} 4 \mathrm{~A}}$ fuse and by the immunohistochemistry using cervical tissue specimens. In contrast, the immunization of mice with the same doses of GST-fused p16 $6^{\mathrm{INK} 4 \mathrm{~A}}$ protein did not induce formation of $\mathrm{p} 16^{\mathrm{INK} 4 \mathrm{~A}}$-specific antibodies, most likely due to the masking of the target sequence by the GST. The immunization of mice with pseudotype VLPs allowed generation of several MAbs that specifically recognized recombinant p $16^{\mathrm{INK} 4 \mathrm{~A}}$ protein by both ELISA and Western blot. Moreover, the reactivity of the MAbs with the intracellular native p16 $6^{\text {INK4A }}$ was demonstrated. The ability of the MAbs to recognize native cellular $\mathrm{p} 16^{\mathrm{INK} 4 \mathrm{~A}}$ suggests proper folding of the target sequence displayed on the surface of pseudotype VLPs. The obtained results demonstrate the efficiency of pseudotype VLPs in presenting foreign protein sequences to $\mathrm{B}$ cells for the generation of target-specific antibodies.

\section{Conclusions}

Hamster polyomavirus-derived proteins VP1 and VP2 capable to self-assemble to VLPs can be employed to construct chimeric proteins with improved immunogenicity. Yeastexpressed pseudotype VLPs consisting of the intact VP1 protein and VP2 protein fused to the cellular antigen p $16^{\mathrm{INK} 4 \mathrm{~A}}$ are immunogenic and induce antibodies specific to the $\mathrm{p} 16^{\mathrm{INK} 4 \mathrm{~A}}$ sequence. The current study demonstrates the potential of pseudotype VLPs with inserted target antigen as a new type of immunogens to generate antibodies of high diagnostic relevance.

\section{Conflict of Interests}

The authors declare that there are no competing interests.

\section{Acknowledgments}

This work was supported by the Lithuanian Science Council (Grant no. AUT-16/2010) and the Agency for Science, Innovations and Technology (Grant no. 31V-116).

\section{References}

[1] K. van Herck, P. van Damme, S. Thoelen, and A. Meheus, "Long-term persistence of anti-HBs after vaccination with a recombinant DNA yeast-derived hepatitis B vaccine: 8-year results," Vaccine, vol. 16, no. 20, pp. 1933-1935, 1998.

[2] M. R. Hilleman, "Yeast recombinant hepatitis B vaccine," Infection, vol. 15, no. 1, pp. 3-7, 1987.

[3] K. E. Palmer, A. B. Jenson, J. C. Kouokam, A. B. Lasnik, and S. J. Ghim, "Recombinant vaccines for the prevention of human papillomavirus infection and cervical cancer," Experimental and Molecular Pathology, vol. 86, no. 3, pp. 224-233, 2009.

[4] P. Pumpens and E. Grens, "Artificial genes for chimeric viruslike particles," in Artificial DNA: Methods and Applications, pp. 249-327, CRC Press, LLC, 2002.

[5] R. Ulrich, M. Nassal, H. Meisel, and D. H. Krüger, "Core particles of hepatitis B virus as carrier for foreign epitopes," Advances in Virus Research, vol. 50, pp. 141-182, 1998.

[6] D. Koletzki, S. S. Biel, H. Meisel et al., "HBV core particles allow the insertion and surface exposure of the entire potentially protective region of puumala hantavirus nucleocapsid protein," The Journal of Biological Chemistry, vol. 380, no. 3, pp. 325-333, 1999.

[7] K. Tegerstedt, J. A. Lindencrona, C. Curcio et al., "A single vaccination with polyomavirus VP1/VP2Her2 virus-like particles prevents outgrowth of HER-2/neu-expressing tumors," Cancer Research, vol. 65, no. 13, pp. 5953-5957, 2005.

[8] A. Gedvilaite, A. Zvirbliene, J. Staniulis, K. Sasnauskas, D. H. Krüger, and R. Ulrich, "Segments of puumala hantavirus nucleocapsid protein inserted into chimeric polyomavirusderived virus-like particles induce a strong immune response in mice," Viral Immunology, vol. 17, no. 1, pp. 51-68, 2004.

[9] A. Zvirbliene, L. Samonskyte, A. Gedvilaite, T. Voronkova, R. Ulrich, and K. Sasnauskas, "Generation of monoclonal antibodies of desired specificity using chimeric polyomavirusderived virus-like particles," Journal of Immunological Methods, vol. 311, no. 1-2, pp. 57-70, 2006.

[10] J. Sambrook and D. W. Russell, Molecular Cloning, A Laboratory Manual, Cold Spring Harbour, Cold Spring Harbor Press, 2001.

[11] R. Slibinskas, D. Samuel, A. Gedvilaite, J. Staniulis, and K. Sasnauskas, "Synthesis of the measles virus nucleoprotein in yeast Pichia pastoris and Saccharomyces cerevisiae," Journal of Biotechnology, vol. 107, no. 2, pp. 115-124, 2004.

[12] G. Kohler and C. Milstein, "Continuous cultures of fused cells secreting antibody of predefined specificity," Nature, vol. 256, no. 5517, pp. 495-497, 1975.

[13] A. Zvirbliene, I. Sezaite, M. Pleckaityte, I. Kucinskaite-Kodze, M. Juozapaitis, and K. Sasnauskas, "Mapping of an antigenic site on the nucleocapsid protein of human parainfluenza virus type 3," Viral Immunology, vol. 22, no. 3, pp. 181-188, 2009.

[14] J. T. Keating, A. Cviko, S. Riethdorf et al., "Ki-67, cyclin E, and p $16^{I N K 4}$ are complimentary surrogate biomarkers for human papilloma virus-related cervical neoplasia," The American Journal of Surgical Pathology, vol. 25, no. 7, pp. 884-891, 2001.

[15] N. Murphy, M. Ring, A. G. Killalea et al., "p $16^{I N K 4 A}$ as a marker for cervical dyskaryosis: CIN and cGIN in cervical biopsies and ThinPrep smears," Journal of Clinical Pathology, vol. 56, no. 1, pp. 56-63, 2003.

[16] M. G. Dijkstra, D. A. M. Heideman, S. C. De Roy et al., "p16" INK4a immunostaining as an alternative to histology review for reliable grading of cervical intraepithelial lesions," Journal of Clinical Pathology, vol. 63, no. 11, pp. 972-977, 2010.

[17] K. Sasnauskas, O. Buzaite, F. Vogel et al., "Yeast cells allow high-level expression and formation of polyomavirus-like particles," Biological Chemistry, vol. 380, no. 3, pp. 381-386, 1999. 
[18] R. C. Liddington, Y. Yan, J. Moulai, R. Sahli, T. L. Benjamin, and S. C. Harrison, "Structure of simian virus 40 at $3.8 \AA$ resolution," Nature, vol. 354, no. 6351, pp. 278-284, 1991.

[19] T. Stehle, Y. Yan, T. L. Benjamin, and S. C. Harrison, "Structure of murine polyomavirus complexed with an oligosaccharide receptor fragment," Nature, vol. 369, no. 6476, pp. 160-163, 1994.

[20] J. P. Griffith, D. L. Griffith, I. Rayment, W. T. Murakami, and D. L. Caspar, "Inside polyomavirus at $25-\AA$ resolution," Nature, vol. 355, no. 6361, pp. 652-654, 1992. 

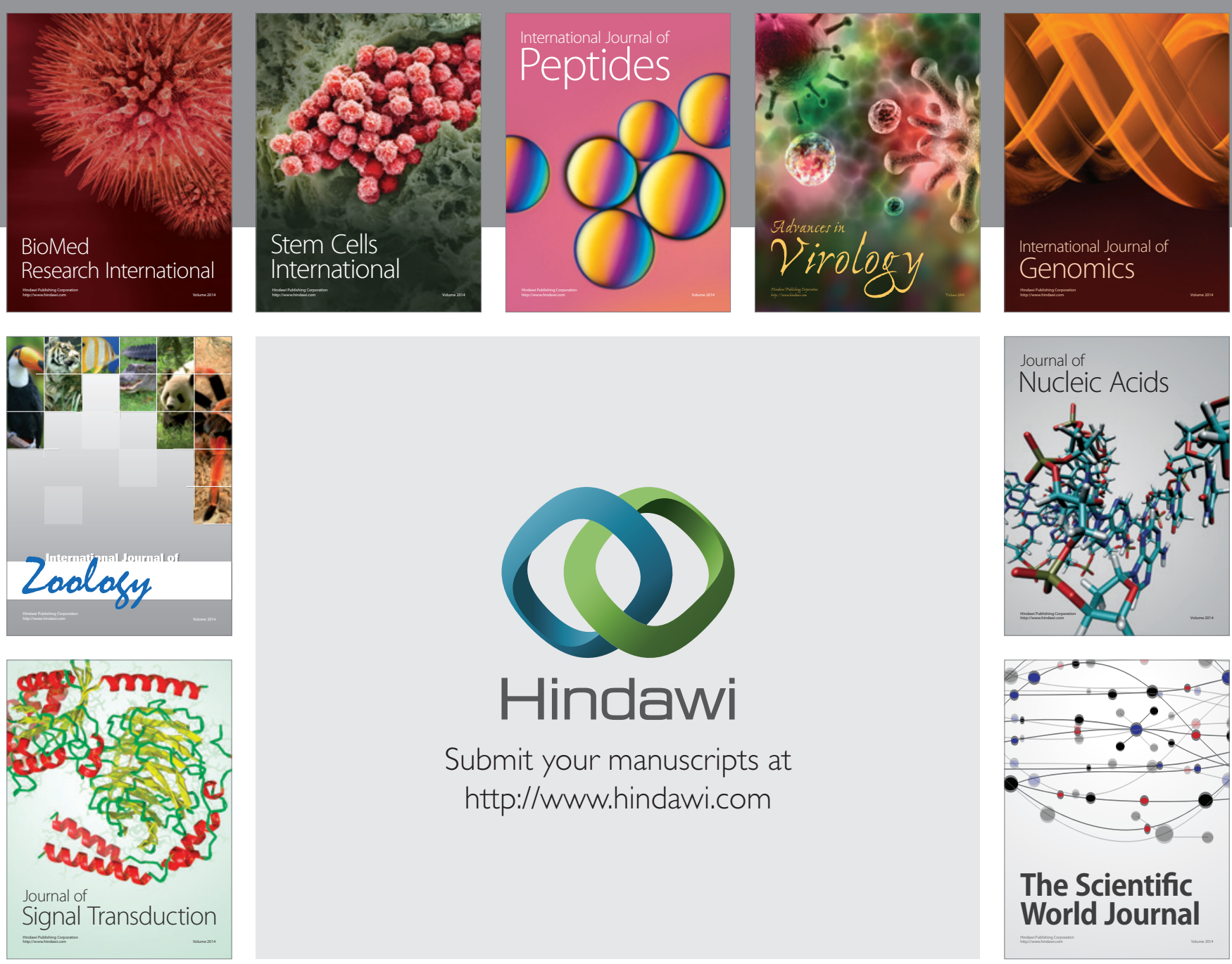

Submit your manuscripts at

http://www.hindawi.com
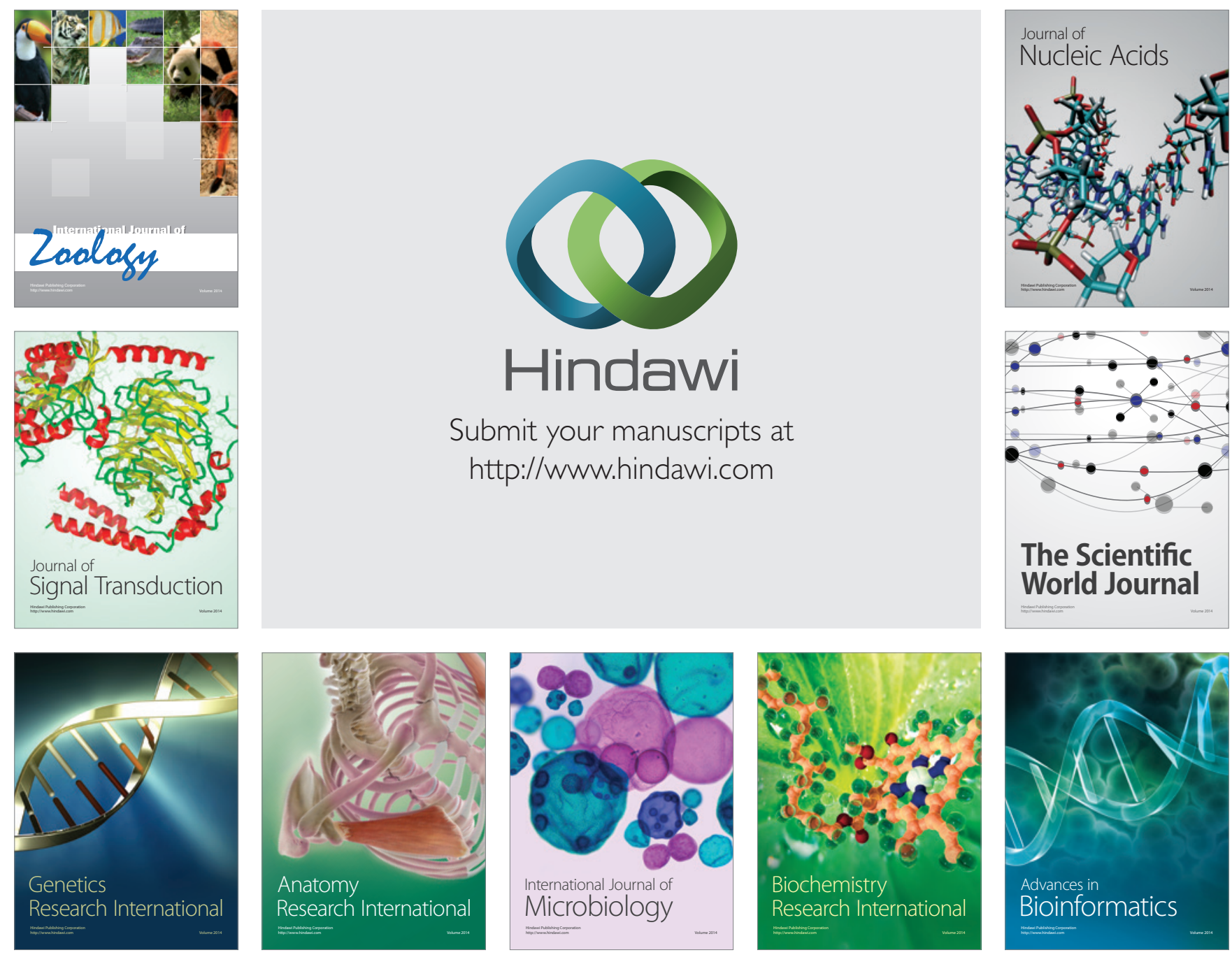

The Scientific World Journal
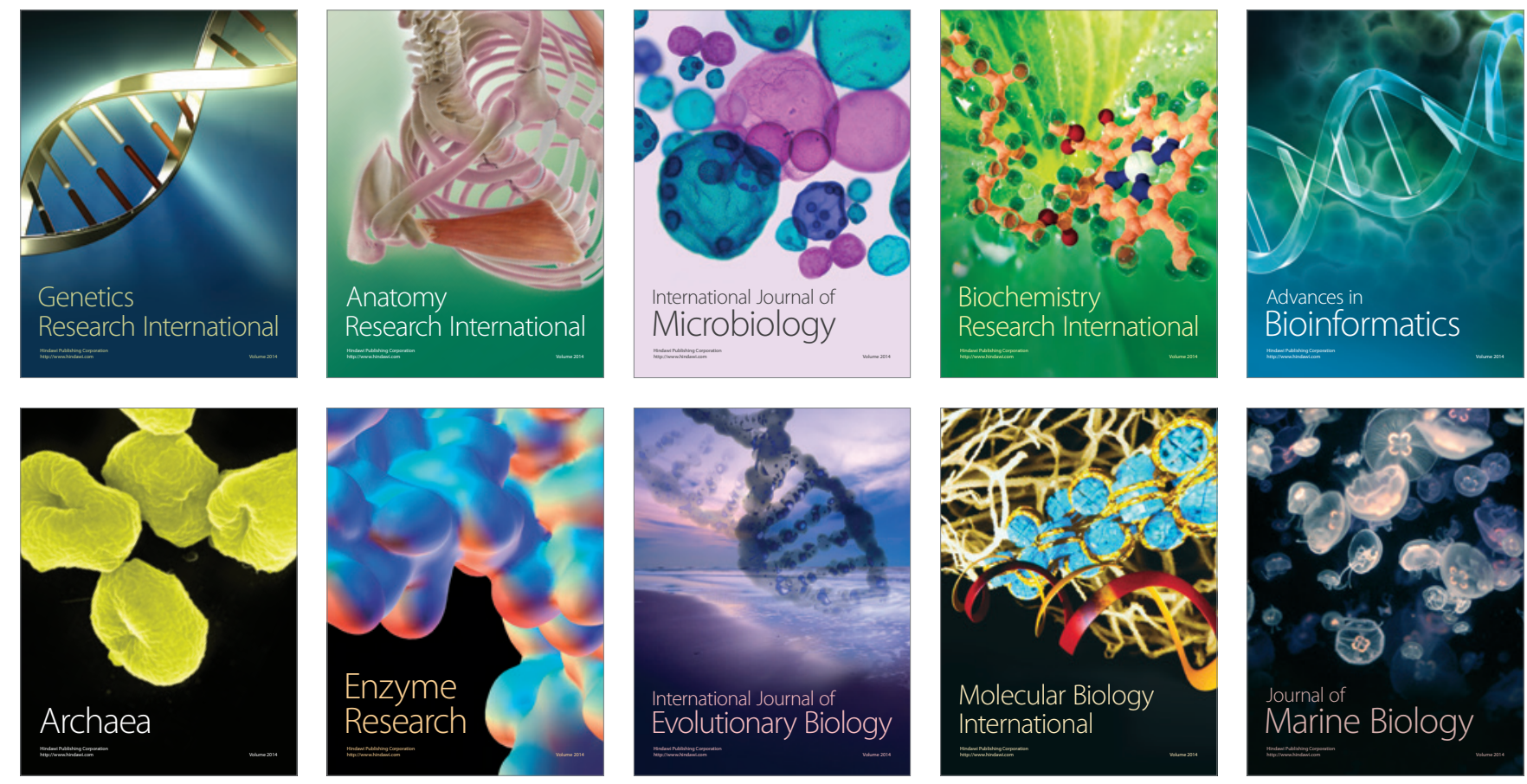